\title{
Expression of bone morphogenetic protein- 2 and its receptors in epithelial ovarian cancer and their influence on the prognosis of ovarian cancer patients
}

Ying $\mathrm{Ma}^{*}$, Lin $\mathrm{Ma}^{*}$, Quan Guo and Shulan Zhang

\begin{abstract}
Background: To determine the expression of bone morphogenetic protein-2 (BMP-2) and its receptors BMPRIA, BMPRIB, and BMPRII in epithelial ovarian cancer (EOC) and to analyze their influence on the prognosis of ovarian cancer patients.

Methods: Semi-quantitative RT-PCR and western blot were applied to detect the expression of BMP-2 and its receptors BMPRIA, BMPRIB, and BMPRII in EOC, benign ovarian tumors, and normal ovarian tissue at the mRNA and protein levels. Immunohistochemistry was used to determine the expression of BMP-2 and its receptors in 100 patients with EOC to analyze their influence on the five-year survival rate and survival time of ovarian cancer patients.

Results: (1) The mRNA and protein expression levels of BMP-2, BMPRIB, and BMPRII in ovarian cancer tissue were remarkably lower than those in benign ovarian tumors and normal ovarian tissue, while no significant differences in BMPRIA expression level was found among the three kinds of tissues. (2) The five-year survival rate and the average survival time after surgery of EOC patients with positive expression of BMP-2, BMPRIB, and BMPRII were remarkably higher than those of patients with negative expression of BMP-2, BMPRIB, and BMPRII. BMPRIA expression was not associated with the five-year survival rate or with the average survival time of ovarian cancer patients.
\end{abstract}

Conclusions: BMP-2, BMPRIB, and BMPRIl exhibited low expression in EOC tissue, and variation or loss of expression may indicate poor prognosis for ovarian cancer patients.

\section{Background}

Ovarian cancer is the most lethal type of malignant tumors of the female reproductive system, and despite recent developments in diagnosis and treatment techniques, the five-year survival rate for ovarian cancer patients is only $20-40 \%[1]$. The low survival rate is likely due to the lack of early symptoms for this cancer; most patients are diagnosed at an advanced stage and exhibit widespread metastasis. At present, the pathological causes of ovarian cancer are unclear. Thus, it is urgent to investigate and search for novel treatment regimens.

The development of tumors is believed to be a complex process involving several genes and several factors, and

*Correspondence: may1@sj-hospital.org, lin.ma@live.se

Department of Obstetrics and Gynecology, Shengjing Hospital of China Medical University, Shenyang 110004, China

Full list of author information is available at the end of the article more and more influencing factors are emerging. In recent years, researchers have focused on the correlation between bone morphogenetic proteins (BMPs) and the presence of tumors. BMP is a member of the transforming growth factor- $\beta$ superfamily. Initially, it was thought to induce bone formation and chondrogenesis in vivo, and current evidence suggests that it also participates in various biological processes of cells, such as proliferation, differentiation, and apoptosis[2]. BMP signaling is mediated by transmembrane serine/threonine kinases, namely, BMPRI (BMPRIA, BMPRIB) and BMPRII receptors[3]. There are 16 kinds of BMPs, and the majority of studies have focused on BMP-2, which has been shown to play a crucial role in the occurrence and development of breast cancer[4-6], lung cancer[7-11], prostatic carcinoma[12-14], and colon cancer[15,16]. However, the cor-

() 2010 Ma et al; licensee BioMed Central Ltd. This is an Open Access article distributed under the terms of the Creative Commons At:-1 Wed Central tribution License (http://creativecommons.org/licenses/by/2.0), which permits unrestricted use, distribution, and reproduction in any medium, provided the original work is properly cited. 
relation between BMP-2 and ovarian cancer remains unclear. This study was designed to determine the expression of BMP-2 and its receptors in epithelial ovarian cancer, benign ovarian tumors, and normal ovarian tissue and to analyze their influence on the five-year survival rate and average survival time of ovarian cancer patients.

\section{Methods \\ Samples}

RT-PCR samples: A total of 29 EOC patients, 32 benign ovarian tumor patients, and 10 patients with normal ovarian tissue were recruited from Shengjing Hospital, which is affiliated with China Medical University, between August 2005 and August 2007.

Western blot samples: A total of 15 EOC patients, 15 benign ovarian tumor patients, and 10 patients with normal ovarian tissue were recruited from Shengjing Hospital, which is affiliated with China Medical University, between August 2005 and August 2007.

Immunohistochemistry samples: One hundred paraffin-embedded specimens of EOC preserved at the Department of Pathology of Shengjing Hospital between January 1997 and August 2001 were included in this study. Specimens were examined for histological grade based on World Health Organization criteria. All EOC patients were grade II and grade III. The tumor stages were determined according to the International Federation of Gynecology and Obstetrics (FIGO) with surgically and cytologically stage performed, all EOC patients had stage III and stage IV. All specimens were fixed with paraformaldehyde, embedded in paraffin, and prepared as serial slices of $4 \mu \mathrm{m}$ in thickness.

All experiment subjects had complete clinical pathological data and were aged 20-72 years (mean: $50.36 \pm 12.30$ ), and there were no significant differences between age groups. No patients received radiotherapy, chemotherapy, biotherapy, or any other operation before surgery for the cancer. Maximal surgical cytoreduction is followed by the standard systemic chemotherapy for these patients. The pathological diagnosis was performed by experts at the Department of Pathology of Shengjing Hospital and the Fourth Hospital affiliated with China Medical University. All samples and clinical data were obtained with the consent from all patients.

\section{Main reagents}

BMP-2 rabbit anti-human polyclonal antibody, SABC immunohistochemical kit, DAB color-developing reagent (Wuhan Boster, China); $\beta$-actin rat anti-human polyclonal antibody, BMPRIA rabbit anti-human polyclonal antibody, BMPRIB rabbit anti-human polyclonal antibody, BMPRII goat anti-human polyclonal antibody (Santa Cruz, USA); BMP-2, BMPRIA, BMPRIB, BMPRII and internal reference $\beta$-actin primers (Shanghai Sangon, China); Trizol total RNA extraction reagent (Invitrogen, USA); RT kit and PCR amplification reagents (TaKaRaDalian, China); alkaline phosphatase-labeled goat antirabbit IgG, rabbit anti-goat IgG (Sigma, USA); Bradford protein kit (Nanjing Keygen, China); nitrocellulose filter (Shanghai Gene, China), $\beta$-naphthyl acid phosphate, Odianisidine (tetrazotized; Sigma, USA).

\section{RT-PCR}

In accordance with the instructions for the Trizol total RNA extraction kit, total RNA was extracted from 100 mg specimens, and the ratio of $\mathrm{OD}_{260}$ and $\mathrm{OD}_{280}$ was 1.82.0. The harvested RNA was diluted to a concentration of $1 \mu \mathrm{g} / \mathrm{ul}$, packaged, and preserved at $-70^{\circ} \mathrm{C}$. The conditions for the first round of RT synthesis of cDNA were as follows: $42^{\circ} \mathrm{C}$ for $30 \mathrm{~min}, 99^{\circ} \mathrm{C}$ for $5 \mathrm{~min}$, and $5^{\circ} \mathrm{C}$ for $5 \mathrm{~min}$. PCR reaction conditions were as follows: for BMP-2, BMPRIA, BMPRII, and $\beta$-actin: $94^{\circ} \mathrm{C}$ for $2 \mathrm{~min}, 94^{\circ} \mathrm{C}$ for $30 \mathrm{~s}, 55^{\circ} \mathrm{C}$ for $30 \mathrm{~s}$, and $72^{\circ} \mathrm{C}$ for $45 \mathrm{~s}$ for a total of 30 cycles, then $72^{\circ} \mathrm{C}$ for $7 \mathrm{~min}$; for BMPRIB: $94^{\circ} \mathrm{C}$ for $2 \mathrm{~min}$, $94^{\circ} \mathrm{C}$ for $30 \mathrm{~s}, 53^{\circ} \mathrm{C}$ for $30 \mathrm{~s}$, and $72^{\circ} \mathrm{C}$ for $45 \mathrm{~s}$, for a total of 30 cycles, then for $72^{\circ} \mathrm{C}$ for $7 \mathrm{~min}$. Primer sequences were as follows:

\section{BMP-2:}

5'-CCAACCATGGATTCGTGGTG-3',

5'- GGTACAGCATCGAGATAGCA-3'

BMPRIA:

5'-AATGGAGTAACCTTAGCACCAGAG-3',

5'-AGCTGAGTCCAGGAACCTGTAC-3'

BMPRIB:

5'- GCAGCACAGACGGATATTGT-3',

5' - TTTCATGCCTCATCAACACT-3'

BMPRII:

5'-ACGGGAGAGAAGACGAGCCT-3',

5'-CTAGATCAAGAGAGGGTTCG-3';

$\beta$-actin:

5'-GTGGGGCGCCCCAGGCACCA-3', 5'-CTCCTTAATGTCACGCACGATTTC-3'

After $1.5 \%$ agarose gel electrophoresis with $1 \mu \mathrm{g} / \mu \mathrm{l}$ ethidium bromide dye, RT-PCR products were observed with a GIS-2020 gel scanning image analytical system. By using DNA Marker DL2000 as the standard molecular weight and $\beta$-actin as an internal reference, the ratio of BMP-2, BMPRIA, BMPRIB, BMPRII, and $\beta$-actin was calculated. RT-PCR products were semiquantitatively analyzed.

\section{Western blot}

In accordance with the instructions for the total protein extraction kit, total protein was extracted from $100 \mathrm{mg}$ specimens. Protein concentrations were assayed by the Bradford method, and specimens were adjusted to the same protein concentration, packaged, and preserved at - 
Table 1: Relative content of mRNA of BMP-2 and its receptors in ovarian tissue

\begin{tabular}{lllll}
\hline & BMP-2 & BMPRIA & BMPRIB & BMPRII \\
\hline Ovarian cancer & $0.875 \pm 0.136$ & $1.525 \pm 0.158$ & $0.808 \pm 0.137$ & $0.834 \pm 0.138$ \\
Benign ovarian tumor & $1.409 \pm 0.089$ & $1.569 \pm 0.198$ & $1.173 \pm 0.143$ & $1.016 \pm 0.119$ \\
Normal ovarian tissue & $1.598 \pm 0.082$ & $1.455 \pm 0.176$ & $1.234 \pm 0.162$ & $1.273 \pm 0.179$ \\
P value & 0.001 & 0.680 & $0.001 \mathrm{a}$ & 0.001 \\
\hline
\end{tabular}

a $P=0.548$, comparison between benign ovarian tumor and normal ovarian tissue.

$70^{\circ} \mathrm{C}$ for later use. With a prestained marker serving as an index, the necessary gels were selected after polyacrylamide gel electrophoresis was performed, and a nitrocellulose filter was used for the transfer print. The primary antibody concentration was $1: 100$ and the secondary antibody was 1:2,000. By using alkaline phosphatase coloration, the protein hybridization band was scanned with a GIS-2020 digital image analysis system and the absorbance value was assayed. The ratios of BMP-2, BMPRIA, BMPRIB, BMPRII, and $\beta$-actin were calculated for the semiquantitative analysis.

\section{Immunohistochemistry}

Paraffin slices were treated according to the SABC immunohistochemical kit, and results were analyzed using a double-blind method. Five high-power fields $(\times 400)$ were selected at random, and two pathologists evaluated scores independently. PBS, instead of the primary antibody, was used as negative control, and specimens were scored according to the intensity of the dye color and the number of positive cells. The intensity of the dye color was graded as 0 (no color), 1 (light yellow), 2 (light brown), or 3 (brown), and the number of positive cells was graded as $0(<5 \%), 1(5-25 \%), 2(25-50 \%), 3(51-75 \%)$, or $4(>75 \%)$. The two grades were added together and specimens were assigned to one of 4 levels: 0-1 score (-), 2

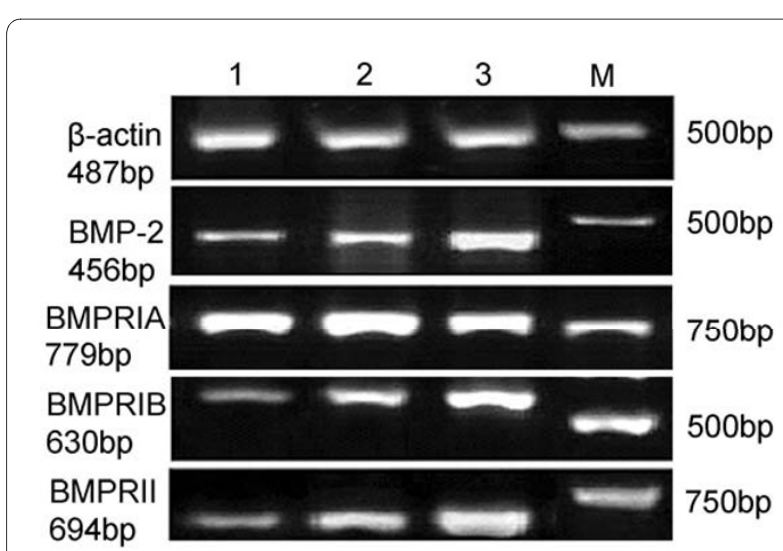

Figure 1 The mRNA expression of BMP-2 and its receptors detected by RT-PCR 1: Ovarian cancer tissue; 2: Benign ovarian tumor tissue; 3: Normal ovarian tissue; M: Marker. scores $(+), 3-4$ scores $(++)$, more than 5 scores $(+++)$. The positive expression rate was expressed as the percent of the addition of $(++)$ and $(+++)$ to the total number.

\section{Statistical analysis}

Statistical analysis was performed with SPSS version 11.0 software, and $P<0.05$ was considered to be statistically significant. Statistical tests used included the chi square test and analysis of variance.

\section{Results}

RT-PCR

The mRNA expression levels of BMP-2, BMPRIB, and BMPRII in ovarian cancer tissues was significantly lower than those in benign ovarian tumors or normal ovarian tissue. No significant differences in BMPRIA mRNA expression level were observed among the three kinds of tissue (Table 1 and Figure 1). The relative content of the proteins was expressed as mean \pm standard deviation (SD).

\section{Western blot}

The relative content of the proteins BMP-2, BMPRIB, and BMPRII in ovarian cancer tissue was significantly lower than those in benign ovarian tumors or normal ovarian tissue. No significant differences in BMPRIA protein expression level were observed among the three kinds of tissue (Table 2 and Figure 2). The relative content was expressed as mean \pm standard deviation (SD).

\section{Immunohistochemistry}

Positively stained BMP-2 and its receptors BMPRIA, BMPRIB, and BMPRII were mainly located in the cytoplasm of ovarian cancer cells and appeared as light brown and brown particles (Figure 3).

Retrospective analysis of follow-up visits of patients showed that the total five-year survival rate of 100 patients was $32 \%$ with a mean survival time of $32.42 \pm$ 22.62 months. The five-year survival rate after surgery of ovarian cancer patients with positive expression of BMP2 , BMPRIB, and BMPRII was remarkably higher than that of patients with negative expression of BMP-2, BMPRIB, and BMPRII. BMPRIA expression was not associated 
Table 2: Relative content of BMP-2 protein of BMP-2 and its receptors in ovarian tissues

\begin{tabular}{lllll}
\hline & BMP-2 & BMPRIA & BMPRIB & BMPRII \\
\hline Ovarian cancer & $0.805 \pm 0.105$ & $0.951 \pm 0.101$ & $0.816 \pm 0.108$ & $0.867 \pm 0.119$ \\
Benign ovarian tumor & $0.958 \pm 0.103$ & $0.911 \pm 0.113$ & $0.905 \pm 0.115$ & $0.974 \pm 0.097$ \\
Normal ovarian tissue & $0.975 \pm 0.082$ & $1.026 \pm 0.099$ & $1.029 \pm 0.087$ & $1.077 \pm 0.103$ \\
P value & 0.019 & 0.361 & 0.042 & 0.043 \\
\hline
\end{tabular}

with the five-year survival rate of ovarian cancer patients (Table 3).

\section{Discussion}

In 1965, Urist successfully induced heterotopic bone formation by grafting decalcified bovine bone into muscles and skin[17]. Accordingly, we conclude that some substance in bone matrix is capable of inducing bone formation, namely BMP. BMP can differentiate mesenchymal cells into osteoblasts, plays various roles during embryonic development, and is of crucial importance to the nervous system, hematopoietic cells, the heart and liver, etc. BMP cannot act without its receptors, namely, BMPRI (BMPRIA and BMPRIB) and BMPRII, which are located on chromosomes 10q23, 4q22-24, and 2q33-34. BMPRIA mediates growth stimulation signals, and BMPRIB transfers growth inhibition signals[3]. BMPs bind with type II receptors first, after which the type II receptor phosphorylates the type I receptor. The receptor-ligand complex phosphorylates the Smad system, and then the complex shifts into the cell nucleus and is involved in gene transcription, thus transferring the BMP signal to the target gene.

At present, there are 16 known BMPs, and the majority of research has focused on BMP-2. In 1988, Wozney screened a gene named hBMP-2 from human U-20S cell cDNA based on a bovine BMP amino acid sequence[18]. The hBMP-2 cDNA was 1188 bp in length, encoded 396

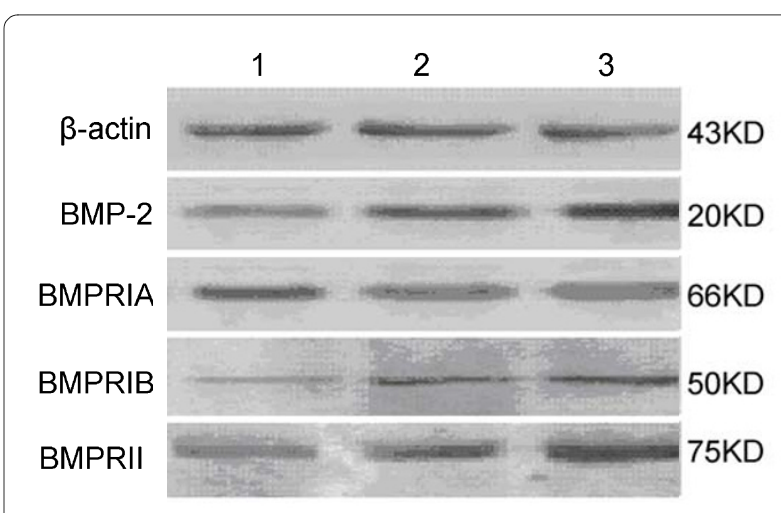

Figure 2 The protein expression of BMP-2 and its receptors detected by western blot 1: Ovarian cancer tissue; 2 : Benign ovarian tumor tissue; 3: Normal ovarian tissue amino acids, and was located on chromosome 20 in the p21 region.

BMP-2 plays an important physiological role in various tissues throughout the body and has been shown to be expressed in tumor tissues. Moreover, its effects vary depending on the tissue. For example, studies have demonstrated that BMP-2 and its receptors are expressed in breast cancer[19], colon cancer[15], gastric cancer[20] and that its expression may be associated with the biological behavior of the tumor. In vitro trials have confirmed that BMP-2 can inhibit the growth of some tumors. Conversely, other research has suggested that BMP-2 can stimulate the growth of tumor cells in vitro, such as lung cancer $[9,10]$ and prostatic carcinoma[21]. There are only a few reports on the correlation of BMP-2 and ovarian cancer. For instance, Kiyozuka [22] and Le Page [23] both detected the expression of BMP-2 in ovarian cancer tissues, and Kiyozuka further confirmed that BMP-2 was involved in the formation of serous ovarian cancer psammoma bodies. Soda[16] has reported that BMP-2 can inhibit the growth of cancer cell clones in 2 of 15 ovarian cancer patients, but no study has investigated the influence of BMP-2 on prognosis for ovarian cancer patients or the underlying mechanisms behind its role in the development of ovarian cancer.

In this study, BMP-2 was shown to be expressed in ovarian cancer, benign ovarian tumors, and normal ovarian tissue, and its expression in ovarian cancer was clearly lower than the latter two. This evidence suggests that the BMP-2 gene is likely expressed in normal ovarian tissue, where it acts as a protective factor. Thus, variation or loss of its expression may promote the development of ovarian cancer. The BMP-2 receptors BMPRIA, BMPRIB, and BMPRII were also expressed in all three types of tissue, and the expression levels of BMPRIB and BMPRII in ovarian cancer tissue was significantly lower than those in benign ovarian tumors and normal ovarian tissue, although the difference in the BMPRIA expression level between the different tissues was not significant. This suggests that BMP-2 may act through its receptors, BMPRIB and BMPRII, in ovarian cancer. Previous studies have shown that BMPRIA mediates growth stimulation signals, while BMPRIB transfers growth inhibition signals. Our evidence suggests that the weakening of the 
Table 3: Correlation of the expression of BMP-2 and its receptors with survival rate and survival time of ovarian cancer patients

\begin{tabular}{lllll}
\hline & BMP2 & BMPRIA & BMPRIB & BMPRII \\
\hline Positive expression rate (\%) & & & 62 & 53 \\
Negative expression rate (\%) & 62 & 49 & 38 & 47 \\
Five-year survival rate of positive cases & 38 & 51 & 41.94 & 41.51 \\
Five-year survival rate of negative cases & 18.32 & 31.67 & 15.79 & 21.28 \\
$P$ value & 0.023 & 0.891 & 0.007 & 0.030 \\
Survival time of negative cases & $37.27 \pm 21.46$ & $33.71 \pm 21.95$ & $37.66 \pm 22.54$ & $37.21 \pm 22.10$ \\
Survival time of negative cases & $24.50 \pm 22.47$ & $31.18 \pm 23.40$ & $23.87 \pm 20.25$ & $27.02 \pm 22.20$ \\
$P$ value & 0.006 & 0.577 & 0.003 & 0.024 \\
\hline
\end{tabular}

inhibitory effect of BMP-2 and BMPRIB may promote the development of ovarian cancer. It is possible that BMPRIA has no correlation with the development of ovarian cancer. That is, the development of ovarian cancer is not due to the stimulatory effect of BMPRIA.

In order to investigate the influence of BMP-2 on the prognosis of ovarian cancer patients, 100 patients were followed up after their surgery. Their five-year survival rate was $32 \%$, a rate that is consistent with other published reports. Immunohistochemistry results demonstrated that ovarian cancer patients with positive expression of BMP-2, BMPRIB, and BMPRII exhibited remarkably higher five-year survival rates and average survival rates than patients with negative expression of BMP-2, BMPRIB, and BMPRII. BMPRIA showed no association with five-year survival rate or with survival time of ovarian cancer patients. BMP-2, BMPRIB, and BMPRII may play a part in the occurrence and development of ovarian cancer, and the variation or loss of

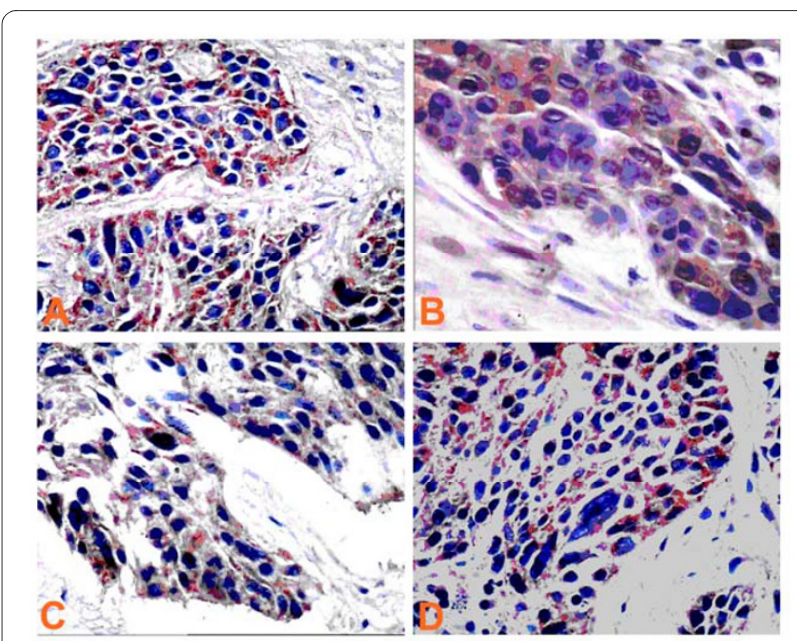

Figure 3 Expression of BMP-2, BMPRIA, BMPRIB, and BMPRII in epithelial serous ovarian cancer detected by immunohistochemistry (×400) A: BMP-2, B: BMPRIA, C: BMPRIB, D: BMPRII. expression of BMP-2, BMPRIB, and BMPRII may be an indicator of poor prognosis for ovarian cancer patients. Further studies conducted with larger sample sizes are needed to confirm this association.

Our study suggests that BMP-2 and its receptors BMPRIB and BMPRII are likely to be involved in the development of ovarian cancer, and attenuation or loss of expression may result in or indicate poor prognosis for ovarian cancer patients. However, the specific pathway and mechanisms driving this effect need further study, if novel treatments for ovarian cancer are to be achieved through better understanding of its pathogenesis.

\section{Conclusions}

BMP-2, BMPRIB, and BMPRII exhibited a low expression in EOC tissue. The variation or loss of expression of these markers may indicate poor prognosis for ovarian cancer patients.

\section{Abbreviation list}

EOC: epithelial ovarian cancer; BMPs: bone morphogenetic proteins; BMP-2: bone morphogenetic protein-2; BMPRIA: bone morphogenetic protein-2 receptor IA; BMPRIB: bone morphogenetic protein-2 receptor IB; BMPRII: bone morphogenetic protein-2 receptor II.

Competing interests

The authors declare that they have no competing interests.

\section{Authors' contributions}

YM carried out RT-PCR and Western blot, performed the statistical analysis and wrote the paper. LM participated in the design of the study and contributed with drafting the manuscript. QG carried out the immunohistochemistry studies. SLZ participated in coordination. All authors read and approved the final manuscript.

\section{Acknowledgements}

This study was supported by China National Nature Science Fund (No.30100104) to Dr. Lin Ma.

\section{Author Details}

Department of Obstetrics and Gynecology, Shengjing Hospital of China Medical University, Shenyang 110004, China 
Received: 18 March 2010 Accepted: 30 June 2010

Published: 30 June 2010

\section{References}

1. Ni X, Gu S, Dai J, Cheng H, Guo L, Li L, Ji C, Xie Y, Ying K, Mao Y: Isolation and characterization of a novel human NM23-H1B gene, a different transcript of NM23-H1. J Hum Genet 2003, 48(2):96-100.

2. Wozney JM: The bone morphogenetic protein family: multifunctional cellular regulators in the embryo and adult. Eur J Oral Sci 1998, 106(Suppl 1):160-166

3. Miyazono K, Kusanagi K, Inoue H: Divergence and convergence of TGFbeta/BMP signaling. J Cell Physiol 2001, 187(3):265-276.

4. Ghosh-Choudhury N, Ghosh-Choudhury G, Celeste A, Ghosh PM, Moyer M, Abboud SL, Kreisberg J: Bone morphogenetic protein-2 induces cyclin kinase inhibitor p21 and hypophosphorylation of retinoblastoma protein in estradiol-treated MCF-7 human breast cancer cells. Biochim Biophys Acta 2000, 1497(2):186-196.

5. Dumont N, Arteaga CL: A kinase-inactive type II TGFbeta receptor impairs BMP signaling in human breast cancer cells. Biochem Biophys Res Commun 2003, 301(1):108-112.

6. Ghosh-Choudhury N, Woodruff K, Qi W, Celeste A, Abboud SL, Ghosh Choudhury G: Bone morphogenetic protein-2 blocks MDA MB 231 human breast cancer cell proliferation by inhibiting cyclin-dependent kinase-mediated retinoblastoma protein phosphorylation. Biochem Biophys Res Commun 2000, 272(3):705-711.

7. Tada A, Nishihara T, Kato H: Bone morphogenetic protein 2 suppresses the transformed phenotype and restores actin microfilaments of human lung carcinoma A549 cells. Oncol Rep 1998, 5(5):1137-1140.

8. Langenfeld EM, Bojnowski J, Perone J, Langenfeld J: Expression of bone morphogenetic proteins in human lung carcinomas. Ann Thorac Surg 2005, 80(3):1028-1032.

9. Langenfeld EM, Calvano SE, Abou-Nukta F, Lowry SF, Amenta P, Langenfeld J: The mature bone morphogenetic protein- 2 is aberrantly expressed in non-small cell lung carcinomas and stimulates tumor growth of A549 cells. Carcinogenesis 2003, 24(9):1445-1454.

10. Langenfeld EM, Langenfeld J: Bone morphogenetic protein-2 stimulates angiogenesis in developing tumors. Mol Cancer Res 2004, 2(3):141-149.

11. Langenfeld EM, Kong Y, Langenfeld J: Bone morphogenetic protein 2 stimulation of tumor growth involves the activation of Smad-1/5. Oncogene 2006, 25(5):685-692.

12. Kumagai T, Tomari K, Shimizu T, Takeda K: Alteration of gene expression in response to bone morphogenetic protein-2 in androgen-dependent human prostate cancer LNCaP cells. Int J Mol Med 2006, 17(2):285-291.

13. Orui $\mathrm{H}$, Imaizumi $\mathrm{S}$, Ogino $\mathrm{T}$, Motoyama T: Effects of bone morphogenetic protein-2 on human tumor cell growth and differentiation: a preliminary report. J Orthop Sci 2000, 5(6):600-604.

14. Horvath LG, Henshall SM, Kench JG, Turner JJ, Golovsky D, Brenner PC, O'Neill GF, Kooner R, Stricker PD, Grygiel JJ, et al:: Loss of BMP2, Smad8, and Smad4 expression in prostate cancer progression. Prostate 2004, 59(3):234-242.

15. Hardwick JC, Van Den Brink GR, Bleuming SA, Ballester I, Van Den Brande JM, Keller JJ, Offerhaus GJ, Van Deventer SJ, Peppelenbosch MP: Bone morphogenetic protein 2 is expressed by, and acts upon, mature epithelial cells in the colon. Gastroenterology 2004, 126(1):111-121.

16. Soda H, Raymond E, Sharma S, Lawrence R, Cerna C, Gomez L, Timony GA, Von Hoff DD, Izbicka E: Antiproliferative effects of recombinant human bone morphogenetic protein-2 on human tumor colony-forming units. Anticancer Drugs 1998, 9(4):327-331

17. Urist MR: Bone: formation by autoinduction. Science 1965 150(698):893-899.

18. Wozney JM, Rosen V, Celeste AJ, Mitsock LM, Whitters MJ, Kriz RW, Hewick RM, Wang EA: Novel regulators of bone formation: molecular clones and activities. Science 1988, 242(4885):1528-1534.

19. Waite KA, Eng C: BMP2 exposure results in decreased PTEN protein degradation and increased PTEN levels. Hum Mol Genet 2003, 12(6):679-684

20. Wen XZ, Miyake S, Akiyama Y, Yuasa Y: BMP-2 modulates the proliferation and differentiation of normal and cancerous gastric cells. Biochem Biophys Res Commun 2004, 316(1):100-106.

21. Feeley BT, Krenek L, Liu N, Hsu WK, Gamradt SC, Schwarz EM, Huard J, Lieberman JR: Overexpression of noggin inhibits BMP-mediated growth of osteolytic prostate cancer lesions. Bone 2006, 38(2):154-166.
22. Kiyozuka Y, Nakagawa H, Senzaki H, Uemura Y, Adachi S, Teramoto Y Matsuyama T, Bessho K, Tsubura A: Bone morphogenetic protein-2 and type IV collagen expression in psammoma body forming ovarian cancer. Anticancer Res 2001, 21(3B):1723-1730.

23. Le Page C, Ouellet V, Madore J, Ren F, Hudson TJ, Tonin PN, Provencher DM, Mes-Masson AM: Gene expression profiling of primary cultures of ovarian epithelial cells identifies novel molecular classifiers of ovarian cancer. Br J Cancer 2006, 94(3):436-445.

doi: $10.1186 / 1756-9966-29-85$

Cite this article as: Ma et al., Expression of bone morphogenetic protein-2 and its receptors in epithelial ovarian cancer and their influence on the prognosis of ovarian cancer patients Journal of Experimental \& Clinical Cancer Research 2010, 29:85

\section{Submit your next manuscript to BioMed Central and take full advantage of:}

- Convenient online submission

- Thorough peer review

- No space constraints or color figure charges

- Immediate publication on acceptance

- Inclusion in PubMed, CAS, Scopus and Google Scholar

- Research which is freely available for redistribution

Submit your manuscript at www.biomedcentral.com/submit
C Biomed Central 